\title{
EFFECTS OF MANAGEMENT PRACTICES ON GRASSLAND BIRDS:
}

\section{SWAINSON'S HAWK}

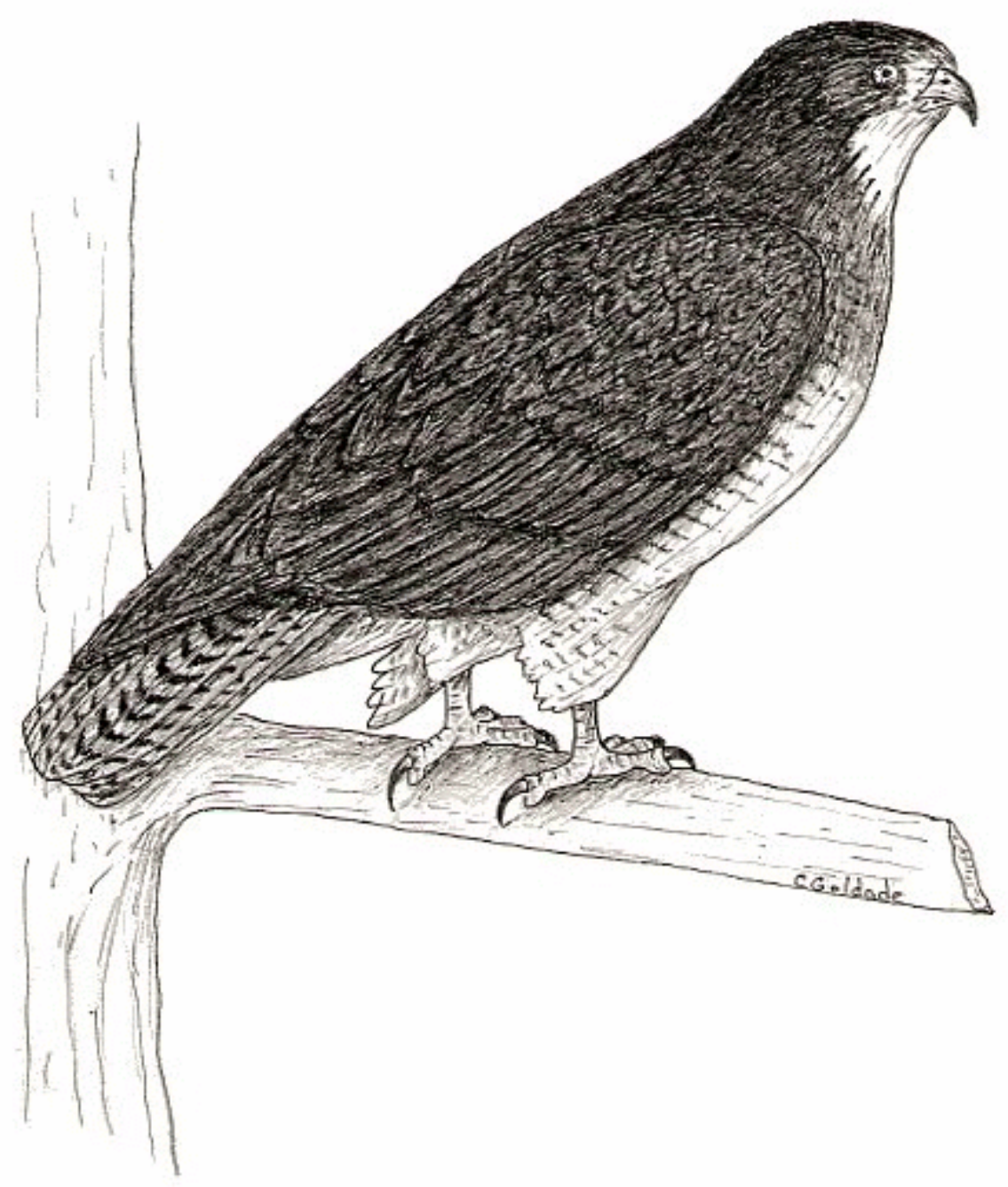

Grasslands Ecosystem Initiative

Northern Prairie Wildlife Research Center

U.S. Geological Survey

Jamestown, North Dakota 58401 
This report is one in a series of literature syntheses on North American grassland birds. The need for these reports was identified by the Prairie Pothole Joint Venture (PPJV), a part of the North American Waterfowl Management Plan. The PPJV recently adopted a new goal, to stabilize or increase populations of declining grassland- and wetland-associated wildlife species in the Prairie Pothole Region. To further that objective, it is essential to understand the habitat needs of birds other than waterfowl, and how management practices affect their habitats. The focus of these reports is on management of breeding habitat, particularly in the northern Great Plains.

Suggested citation:

Dechant, J. A., M. F. Dinkins, D. H. Johnson, L. D. Igl, C. M. Goldade, and B. R. Euliss. 2000 (revised 2001). Effects of management practices on grassland birds: Swainson's Hawk. Northern Prairie Wildlife Research Center, Jamestown, ND. 17 pages.

Species for which syntheses are available or are in preparation:

American Bittern

Mountain Plover

Marbled Godwit

Long-billed Curlew

Willet

Wilson's Phalarope

Upland Sandpiper

Greater Prairie-Chicken

Lesser Prairie-Chicken

Northern Harrier

Swainson's Hawk

Ferruginous Hawk

Short-eared Owl

Burrowing Owl

Horned Lark

Sedge Wren

Loggerhead Shrike

Sprague's Pipit
Grasshopper Sparrow

Baird's Sparrow

Henslow's Sparrow

Le Conte's Sparrow

Nelson's Sharp-tailed Sparrow

Vesper Sparrow

Savannah Sparrow

Lark Sparrow

Field Sparrow

Clay-colored Sparrow

Chestnut-collared Longspur

McCown's Longspur

Dickcissel

Lark Bunting

Bobolink

Eastern Meadowlark

Western Meadowlark

Brown-headed Cowbird 


\section{EFFECTS OF MANAGEMENT PRACTICES ON GRASSLAND BIRDS:}

\section{SWAINSON'S HAWK}

Jill A. Dechant, Meghan F. Dinkins, Douglas H. Johnson, Lawrence D. Igl, Christopher M. Goldade, and Betty R. Euliss

Series Coordinator: Douglas H. Johnson

Series Assistant Coordinator: Lawrence D. Igl

Reviewer: Joseph K. Schmutz

Range Map: Jeff T. Price

Cover Art: Christopher M. Goldade

Major Funding: Prairie Pothole Joint Venture, U.S. Fish and Wildlife Service U.S. Geological Survey

Funding also provided by: U.S. Forest Service

The Nature Conservancy

\section{Collaborators:}

Louis B. Best, Iowa State University

Carl E. Bock, University of Colorado

Brenda C. Dale, Canadian Wildlife Service

Stephen K. Davis, Saskatchewan Wetland Conservation Corporation

James J. Dinsmore, Iowa State University

James K. Herkert, Illinois Endangered Species Protection Board

Fritz L. Knopf, Midcontinent Ecological Science Center

Rolf R. Koford, Iowa Cooperative Fish and Wildlife Research Unit

David R. C. Prescott, Alberta NAWMP Centre

Mark R. Ryan, University of Missouri

David W. Sample, Wisconsin Department of Natural Resources

David A. Swanson, Ohio Division of Wildlife

Peter D. Vickery, Massachusetts Audubon Society

John L. Zimmerman (retired), Kansas State University

January 2000

(revised January 2001) 


\section{ORGANIZATION AND FEATURES OF THIS SPECIES ACCOUNT}

Information on the habitat requirements and effects of habitat management on grassland birds were summarized from information in more than 4,000 published and unpublished papers. A range map is provided to indicate the relative densities of the species in North America, based on Breeding Bird Survey (BBS) data. Although birds frequently are observed outside the breeding range indicated, the maps are intended to show areas where managers might concentrate their attention. It may be ineffectual to manage habitat at a site for a species that rarely occurs in an area. The species account begins with a brief capsule statement, which provides the fundamental components or keys to management for the species. A section on breeding range outlines the current breeding distribution of the species in North America, including areas that could not be mapped using BBS data. The suitable habitat section describes the breeding habitat and occasionally microhabitat characteristics of the species, especially those habitats that occur in the Great Plains. Details on habitat and microhabitat requirements often provide clues to how a species will respond to a particular management practice. A table near the end of the account complements the section on suitable habitat, and lists the specific habitat characteristics for the species by individual studies. A special section on prey habitat is included for those predatory species that have more specific prey requirements. The area requirements section provides details on territory and home range sizes, minimum area requirements, and the effects of patch size, edges, and other landscape and habitat features on abundance and productivity. It may be futile to manage a small block of suitable habitat for a species that has minimum area requirements that are larger than the area being managed. The Brown-headed Cowbird (Molothrus ater) is an obligate brood parasite of many grassland birds. The section on cowbird brood parasitism summarizes rates of cowbird parasitism, host responses to parasitism, and factors that influence parasitism, such as nest concealment and host density. The impact of management depends, in part, upon a species' nesting phenology and biology. The section on breeding-season phenology and site fidelity includes details on spring arrival and fall departure for migratory populations in the Great Plains, peak breeding periods, the tendency to renest after nest failure or success, and the propensity to return to a previous breeding site. The duration and timing of breeding varies among regions and years. Species' response to management summarizes the current knowledge and major findings in the literature on the effects of different management practices on the species. The section on management recommendations complements the previous section and summarizes specific recommendations for habitat management provided in the literature. If management recommendations differ in different portions of the species' breeding range, recommendations are given separately by region. The literature cited contains references to published and unpublished literature on the management effects and habitat requirements of the species. This section is not meant to be a complete bibliography; a searchable, annotated bibliography of published and unpublished papers dealing with habitat needs of grassland birds and their responses to habitat management is posted at the Web site mentioned below.

This report has been downloaded from the Northern Prairie Wildlife Research Center WorldWide Web site, www.npwrc.usgs.gov/resource/literatr/grasbird/grasbird.htm. Please direct comments and suggestions to Douglas H. Johnson, Northern Prairie Wildlife Research Center, U.S. Geological Survey, 8711 37th Street SE, Jamestown, North Dakota 58401; telephone: 701253-5539; fax: 701-253-5553; e-mail: Douglas_H_Johnson@usgs.gov. 


\section{SWAINSON'S HAWK}

(Buteo swainsoni)

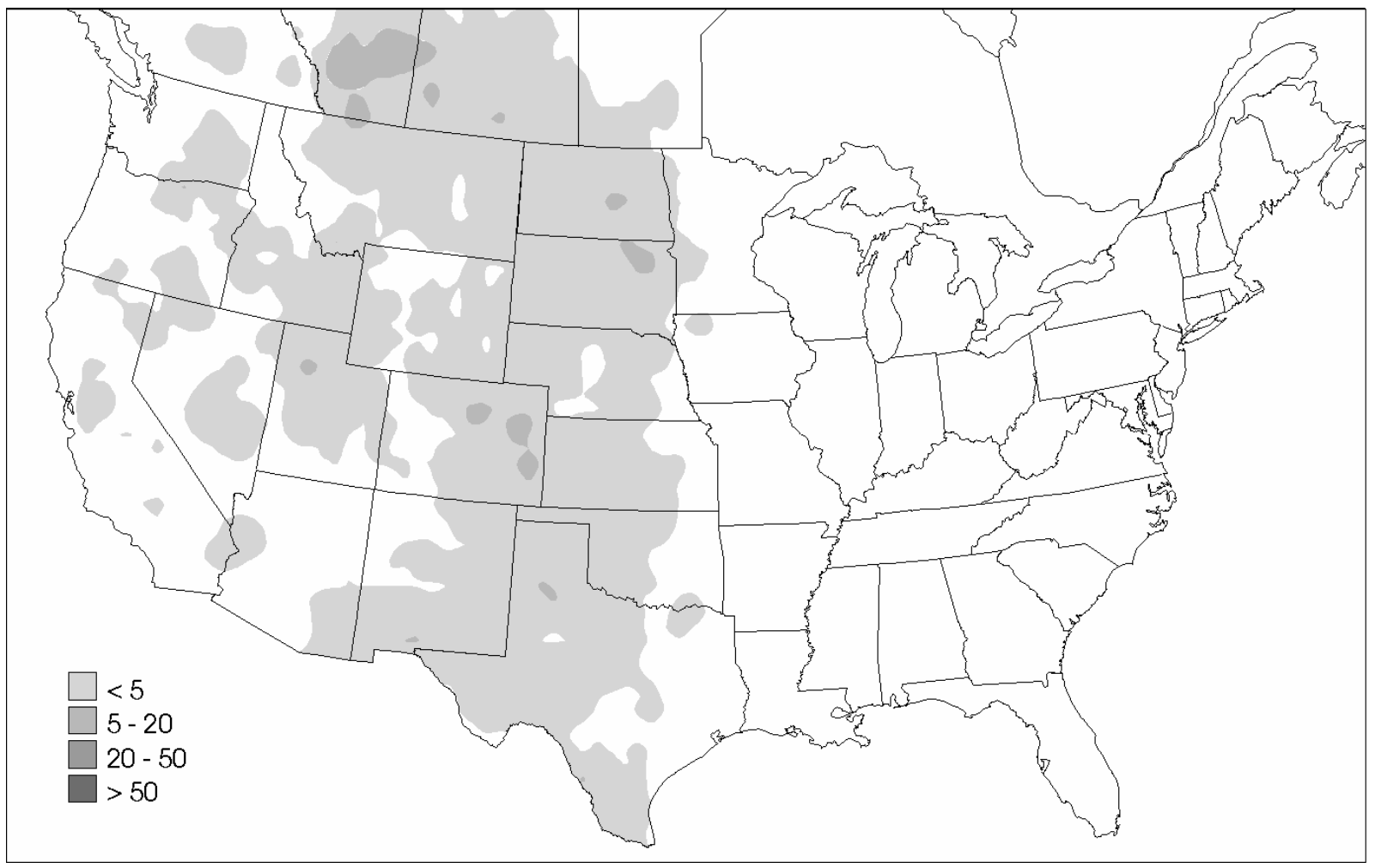

Figure. Breeding distribution of Swainson's Hawk in the United States and southern Canada, based on Breeding Bird Survey data, 1985-1991. Scale represents average number of individuals detected per route per year. Map from Price, J., S. Droege, and A. Price. 1995. The summer atlas of North American birds. Academic Press, London, England. 364 pages.

Key to management is providing open grasslands that contain patches of trees for nesting and perching and that are near cultivated areas.

\section{Breeding range:}

Swainson's Hawks breed from the southern Yukon Territories, through western British Columbia, to southern Alberta, Saskatchewan, and southwestern Manitoba, south from Washington, Idaho, Montana, and North Dakota to California, Arizona, and New Mexico, and east to western Minnesota, northwestern Iowa, northwestern Missouri, Nebraska, central Oklahoma, and central Texas (National Geographic Society 1999). (See figure for the relative densities of Swainson's Hawks in the United States and southern Canada, based on Breeding Bird Survey data.)

\section{Suitable habitat:}

Swainson's Hawks prefer open grassland areas with scattered trees or with small clumps of trees or shrubs (Bent 1961, England et al. 1997). They use shortgrass, mixed-grass, tallgrass, 
and sandhill prairies; aspen parklands; riparian areas; isolated trees; shelterbelts; woodlots; black-tailed prairie dog (Cynomys ludovicianus) colonies; pastures; hayland; and cropland (Saunders 1914, Bent 1961, Jacobson 1972, Stewart 1975, Dunkle 1977, Emmerich 1978, Johnsgard 1980, Clark et al. 1982, Faanes 1983, Gilmer and Stewart 1984, Schmutz 1987, Cable et al. 1992, Leslie 1992, Andersen 1995, Faanes and Lingle 1995, Haas 1997, Prescott 1997, Martell et al. 1998).

Swainson's Hawks nest in trees and shrubs that are either isolated, clumped, or part of shelterbelts (Cameron 1913; Saunders 1914; Bent 1961; Olendorff 1973; Maher 1974; Salt and Salt 1976; Dunkle 1977; Green and Morrison 1983; Thurow and White 1983; Schmutz 1984; Murphy 1991, 1993; Cable et al. 1992; Hansen 1994; Faanes and Lingle 1995; Hansen and Flake 1995). Nest height ranges from 0 to18 m (Bent 1961, Stewart 1975, Dunkle 1977, Schmutz 1977, Munro and Reid 1982, Green and Morrison 1983, Gilmer and Stewart 1984, Restani 1991, Murphy 1993, Hansen 1994), whereas height of nest trees range from 2 to $22 \mathrm{~m}$ (Green and Morrison 1983, Restani 1991, Leslie 1992, Murphy 1993, Hansen 1994). Swainson’s Hawks occasionally nest on artificial nest platforms or on the ground (Salt and Salt 1976, Schmutz 1977, Schmutz et al. 1984). They also have been reported nesting on the crossbars of telephone poles and on railway signal gantries (Dunkle 1977, James 1992).

Individual hawks respond differently to human disturbance (Dunkle 1977) and a tendency towards nest desertion appears to vary regionally (Fyfe and Olendorff 1976). Fyfe and Olendorff (1976) reported that in northeastern Colorado, Swainson’s Hawks disturbed during late incubation did not desert nests. However, researchers in Alberta and Saskatchewan did not bother Swainson's Hawks during incubation because of their tendency to desert nests (Fyfe and Olendorff 1976). Dunkle (1977) found that some female hawks would allow a human to approach within a few meters of the nest before flushing, whereas other hawks would stay several hundred meters away if a human was near the nest. Males usually stayed twice as far away as females. About one-third of incubating females would not flush from their nests unless the observer climbed the nest tree, whereas brooding females frequently would flush from nests if a human walked nearby. In Alberta, Swainson's Hawks flushed from their nests when approaching humans were an average of $18 \mathrm{~m}$ from the nest (Schmutz 1987). Cameron (1913) found that one female Swainson's Hawk would allow people to stand directly under the nest tree, even when the people were talking loudly. A table near the end of the account lists the specific habitat characteristics for Swainson's Hawks by study.

\section{Prey habitat:}

Swainson's Hawks prey primarily on insects and small mammals (Cameron 1913; Olendorff 1973; Salt and Salt 1976; Dunkle 1977; Schmutz 1977; Gilmer and Stewart 1984; Torrance 1986; Johnson et al. 1987; McGrath 1988; Houston 1990, 1995, 1998; Restani 1991; James 1992; Hansen 1994). Other mammals, birds, fish, reptiles, and amphibians also are preyed upon (Cameron 1913, Krause 1968, Olendorff 1973, Dunkle 1977, Schmutz 1977, Gilmer and Stewart 1984, Torrance 1986, Restani 1991, Hansen 1994, Andersen 1995, Knopf 1996). In Idaho, a group ranging in size from 31 to 238 Swainson's Hawks was attracted to a grasshopper (Melanoplus spp.) infestation in June, and each hawk fed on about 100 grasshoppers per day (Johnson et al. 1987). It was estimated that hawks consumed 310,000 grasshoppers while on the study area. 
Swainson's Hawks may favor nest sites near either very low amounts of cropland, because of greater prey densities there, or very high amounts of cropland, because of the ease with which prey can be captured in harvested fields (Groskorth 1995).

\section{Area requirements:}

Estimates of home range size vary from 6.2 to $27.3 \mathrm{~km}^{2}$ (Schmutz 1977, Andersen 1995). In Colorado, males had larger $\left(31.7 \mathrm{~km}^{2}\right)$ home ranges than females $\left(19.9 \mathrm{~km}^{2}\right.$ ) (Andersen 1995). In Alberta, the minimum radius of nesting territories was $0.35 \mathrm{~km}$, with the assumption that nesting territories were circular and were centered on the nest site (Schmutz 1977).

\section{Brown-headed Cowbird brood parasitism:}

No known records of brood parasitism by Brown-headed Cowbirds (Molothrus ater) exist.

\section{Breeding-season phenology and site fidelity:}

Swainson's Hawks occur on breeding areas from late March to early May through late November (Cameron 1913, Olendorff 1973, Maher 1974, Salt and Salt 1976, Janssen 1987, Houston 1990, Hansen 1994, Martell et al. 1998). In Nebraska, Swainson's Hawks arrive from their wintering grounds as early as January and depart as late as December (Johnsgard 1980). They often reuse nests built in previous years (Hansen 1994, Martell et al. 1998). Fidelity to mates and to nest sites has been documented (Houston 1990, Schmutz 1991, Andersen 1995). In Alberta, Swainson's Hawks did not change mates or territories in years following unsuccessful reproductive years (Schmutz 1991). Swainson's Hawks are known to renest following a nesting failure (Olendorff 1973, Leslie 1992).

\section{Species' response to management:}

Few studies have examined the effects of burning, mowing, or grazing on Swainson's Hawks. A number of researchers have investigated the influence of surrounding land use on nest placement and found that the proportion of cultivated land and grassland in the vicinity of nest sites was an important factor (Gilmer and Stewart 1984; Schmutz 1984, 1987, 1989; Groskorth 1995). Within the nesting area in southeastern Alberta, Swainson's Hawks preferred cultivated land over grassland (Schmutz 1987, 1989). Swainson’s Hawks tolerated extensive (up to 90\%) cultivation in the landscape surrounding nest sites as long as $10 \%$ remained in native grassland. In contrast, in the Regina Plain of Saskatchewan, Groskorth (1995) reported that Swainson's Hawks nested in areas with more grassland, trees, and shrubs and fewer wheat fields within $1 \mathrm{~km}$ of the nest site than random sites. Habitat use in Schmutz' (1989) study was examined within $41-\mathrm{km}^{2}$ plots in which the primary land use was cattle grazing or cultivation of cereal grains; cultivation on 80 plots ranged from 0 to $99 \%$. Nest density was higher on areas with 11-30\% cultivation than on areas with $<11 \%$ cultivation (Schmutz 1984). Nest densities increased as cultivation increased to 30\% and then showed no further change (Schmutz 1989). Of 37 nesting pairs, $57 \%$ that nested within $1 \mathrm{~km}$ of cultivated fields raised $\geq 2$ young, compared to $28 \%$ of pairs that nested $>1 \mathrm{~km}$ from cultivated fields (Schmutz 1987). Groskorth's (1995) study area consisted mainly of wheat fields; few natural grasslands or trees remained. Nests were farther from buildings and water and were closer to human communities $>2 \mathrm{~km}^{2}$ in size than to human communities $<2 \mathrm{~km}^{2}$ in size; large human communities may have been attractive to hawks 
because of high tree density near human habitation. Of 34 nest sites, 11 nest sites were in areas where the percentage of wheat within $1 \mathrm{~km}$ of the nest site was $<5 \%$, but 15 nest sites were in areas with $>75 \%$ wheat surrounding the nest site. For 27 nests in North Dakota, land use was recorded both within $100 \mathrm{~m}$ and within $1 \mathrm{~km}$ of nests (Gilmer and Stewart 1984). Mixed-grass pasture and hayland were the dominant land uses within both $100 \mathrm{~m}$ and $1 \mathrm{~km}$ of nest sites. Some Swainson's Hawk pairs tolerated agricultural disturbance: two pairs nested where cropland area within $1 \mathrm{~km}$ was $>60 \%$, and two pairs nested in sites surrounded by cultivated crops within $100 \mathrm{~m}$. In a landscape dominated by agriculture in Manitoba, four nests were surrounded by cropland and four were near native grass or pasture (Munro and Reid 1982).

In and adjacent to the Pawnee National Grassland in Colorado, 90 nests were in natural settings such as creek bottoms or grasslands, whereas 60 nests were in trees near human-created structures such as abandoned farmsteads, ditches, and created ponds (Olendorff 1973). Nests on the Pawnee National Grassland had higher apparent nest success (not statistically tested) than nests on private lands. Remote nests or nests on posted land (i.e., with limited access or no trespassing allowed) were more successful than easily accessible nests or nests near unposted land. Nests near roads were more successful than nests away from roads; nests near unimproved roads (trails used by farmers and ranchers) were more successful than nests near improved (paved or gravel) roads; and nests near posted roads were more successful than nests on unposted roads. Of 157 nests found in the Pawnee National Grassland, 118 were in grassland, 25 in abandoned cropland fields, and 14 in cultivated land (Leslie 1992). In relatively undisturbed Idaho shrubsteppe, nesting pairs had more primary and secondary roads near their nests than did random points (Hansen 1994). The mean distance from a nest to buildings was $8.9 \mathrm{~km}$, to primary roads was $3.4 \mathrm{~km}$, and to secondary roads was $2.8 \mathrm{~km}$. The mean length of road within $3 \mathrm{~km}$ of nests was $20.6 \mathrm{~km}$.

Of 17 eggs collected in the prairie regions of Canada during a period (1966-1988) of extensive organochloride use, three eggs had critical levels of dieldrin and one egg had critical levels of heptachlor epoxide (Noble and Elliot 1990). Swainson's Hawk eggs from Saskatchewan and Alberta showed significant declines in dieldrin levels by 1988, but levels of dichlorodiphenyldichloroethylene (DDE) and heptachlor epoxide had not declined (Noble and Elliot 1990). In western Saskatchewan, unhatched eggs in nests of Swainson's Hawks were examined for possible effects of pesticide contamination; organochlorine was not found to be responsible for lack of hatching (Houston et al. 1991).

\section{Management Recommendations:}

In the absence of large tracts of native prairie, Swainson's Hawks will breed in small patches of natural or semi-natural cover containing trees near cultivated areas (Schmutz 1987).

Plant trees and, if necessary, build livestock exclosures around existing stands of trees to provide and protect nesting sites (Olendorff and Stoddart 1974).

Provide artificial nest sites for Swainson's Hawks near cultivated lands where nest trees are limiting (Olendorff 1973). Place wire-basket nest structures in known nesting trees to reduce destruction of nests by wind. 
Table. Swainson’s Hawk habitat characteristics.

\begin{tabular}{|c|c|c|c|}
\hline Author(s) & Location(s) & Habitat(s) Studied* & Species-specific Habitat Characteristics \\
\hline Andersen 1995 & Colorado & $\begin{array}{l}\text { Shortgrass pasture, } \\
\text { woodland }\end{array}$ & $\begin{array}{l}\text { Nested in one-seeded junipers (Juniperus monosperma), } \\
\text { cottonwoods (Populus spp.), elm (Ulmus sp.), and } \\
\text { twoneedle pine (Pinus edulis) }\end{array}$ \\
\hline Bent 1961 & $\begin{array}{l}\text { North Dakota, } \\
\text { Saskatchewan }\end{array}$ & $\begin{array}{l}\text { Idle mixed-grass, } \\
\text { woodland }\end{array}$ & $\begin{array}{l}\text { In North Dakota, nested in tree groves and shelterbelts; } \\
\text { nests were } 12 \mathrm{~m} \text { above ground in elm, } 4.6 \mathrm{~m} \text { above ground } \\
\text { in oak (Quercus sp.), } 2.4 \mathrm{~m} \text { above ground in a small tree, } \\
\text { and } 4.3 \mathrm{~m} \text { above ground in a cottonwood. In } \\
\text { Saskatchewan, nested along streams in cottonwoods and } \\
\text { other poplars (Populus spp.), in willow (Salix), box elder } \\
\text { (Acer negundo), on the shelf of a cutbank in open country, } \\
\text { on the ground in a patch of bushes, and in a lone poplar on } \\
\text { an open plain; nests ranged in height from } 2.0 \text { to } 10.7 \mathrm{~m} \\
\text { above ground }\end{array}$ \\
\hline Cable et al. 1992 & Kansas & Woodland & Nested in windbreaks \\
\hline Cameron 1913 & Montana & $\begin{array}{l}\text { Idle shortgrass, } \\
\text { shortgrass pasture }\end{array}$ & $\begin{array}{l}\text { Nested in white ash (Fraxinus americana), cottonwood, } \\
\text { cedar (Juniperus), pine (Pinus), and in a low tree by a } \\
\text { roadside }\end{array}$ \\
\hline Clark et al. 1982 & $\begin{array}{l}\text { Colorado, New } \\
\text { Mexico, Utah }\end{array}$ & $\begin{array}{l}\text { Colonies of burrowing } \\
\text { mammals, idle shortgrass }\end{array}$ & $\begin{array}{l}\text { Were observed on black-tailed prairie dog (Cynomys } \\
\text { ludovicianus) colonies, which generally were found in } \\
\text { shortgrass prairie }\end{array}$ \\
\hline Dunkle 1977 & Wyoming & $\begin{array}{l}\text { Idle shortgrass, } \\
\text { shrubsteppe, wet } \\
\text { meadow }\end{array}$ & $\begin{array}{l}\text { Nested on the crossbars of a telephone pole, in narrowleaf } \\
\text { cottonwood (Populus angustifolia) or peachleaf willow } \\
\text { (Salix amygdaloides), in willow shrubs }<5 \text { m high; nest } \\
\text { trees were isolated or in tree clumps, in dry grass, in }\end{array}$ \\
\hline
\end{tabular}




\begin{tabular}{|c|c|c|c|}
\hline & & & $\begin{array}{l}\text { irrigated meadows, or near the edge of these habitat types; } \\
\text { nest height in trees (measured from the top of the nest to } \\
\text { the ground) ranged from } 2.0 \text { to } 11.6 \mathrm{~m} \text { with a mean of } 7.6 \\
\text { m, whereas nest height in shrubs ranged from } 2.0 \text { to } 4.3 \mathrm{~m} \\
\text { with a mean of } 2.4 \mathrm{~m} \text {; the most successful nests were the } \\
\text { six lowest nests that were }<2.5 \mathrm{~m} \text { from the ground; did not } \\
\text { nest near houses }\end{array}$ \\
\hline Emmerich 1978 & South Dakota & Woodland & $\begin{array}{l}\text { Were found in tree claims (nonlinear plantings of trees } \\
\geq 2.1 \text { ha not planted in rows) that were heavily grazed and } \\
\text { that contained many dead trees, few or no shrubs, and low } \\
\text { volume of tree foliage }\end{array}$ \\
\hline Faanes 1983 & North Dakota & $\begin{array}{l}\text { Idle mixed-grass, mixed- } \\
\text { grass pasture, woodland }\end{array}$ & $\begin{array}{l}\text { Were common in native prairie associated with wooded } \\
\text { draws }\end{array}$ \\
\hline Faanes and Lingle 1995 & Nebraska & $\begin{array}{l}\text { Cropland, idle mixed- } \\
\text { grass, idle shortgrass, } \\
\text { idle tallgrass, pasture, } \\
\text { tame hayland, wet } \\
\text { meadow, wetland, } \\
\text { woodland }\end{array}$ & $\begin{array}{l}\text { Nested in upland prairie in single trees or in shelterbelts } \\
\text { adjacent to grassland }\end{array}$ \\
\hline Gilmer and Stewart 1984 & North Dakota & $\begin{array}{l}\text { Cropland, hayland, idle, } \\
\text { mixed-grass pasture, } \\
\text { tame pasture, wetland, } \\
\text { woodland }\end{array}$ & $\begin{array}{l}\text { Nested in shelterbelts, wetland borders, abandoned } \\
\text { farmsteads, rights-of-way, isolated trees, tree claims } \\
\text { (clumped trees other than 1- or 2-row shelterbelts), } \\
\text { coulees, and active farmsteads; 75\% of nests sites were } \\
\text { directly or indirectly produced by humans; nested in } \\
\text { cottonwood (Populus deltoides), Chinese elm (Ulmus } \\
\text { parvifolia), peachleaf willow, box elder, green ash } \\
\text { (Fraxinus pennsylvanica), American elm (U. americana), } \\
\text { and Russian olive (Elaeagnus angustifolia)-all but } \\
\text { cottonwood and willow were planted by humans; nest }\end{array}$ \\
\hline
\end{tabular}




\begin{tabular}{|c|c|c|c|}
\hline & & & $\begin{array}{l}\text { height ranged from } 2.1 \text { to } 17.8 \mathrm{~m} \text { above ground; land use } \\
\text { within } 100 \mathrm{~m} \text { and } 1 \mathrm{~km} \text { of occupied nests was mostly } \\
\text { pasture and hayland; some nesting pairs tolerated } \\
\text { agricultural disturbance: two pairs nested where cropland } \\
\text { area within } 1 \mathrm{~km} \text { was }>60 \% \text {, and two pairs nested in sites } \\
\text { surrounded by } 100 \mathrm{~m} \text { of cultivated crops }\end{array}$ \\
\hline $\begin{array}{l}\text { Green and Morrison } \\
1983\end{array}$ & Oregon & Shrubsteppe & $\begin{array}{l}\text { Nests were at an average height of } 4.7 \mathrm{~m} \text { above ground; } \\
\text { nest trees had an average height of } 6.2 \mathrm{~m}\end{array}$ \\
\hline Groskorth 1995 & Saskatchewan & $\begin{array}{l}\text { Cropland, tame } \\
\text { grassland, woodland }\end{array}$ & $\begin{array}{l}\text { Preferred nesting in areas with less wheat and more } \\
\text { grassland, trees, and shrubs surrounding the nest than at } \\
\text { random sites; nest sites were farther from buildings and } \\
\text { water and closer to larger }\left(>2 \mathrm{~km}^{2}\right) \text { human communities } \\
\text { than were random sites; of } 34 \text { nest sites, } 32 \% \text { were in areas } \\
\text { with }<5 \% \text { wheat within } 1 \mathrm{~km} \text { of the nest and } 44 \% \text { were in } \\
\text { areas with }>75 \% \text { wheat within } 1 \mathrm{~km} \text { of the nest }\end{array}$ \\
\hline Haas 1997 & North Dakota & Woodland & Nested in shelterbelts and along wooded creeks \\
\hline $\begin{array}{l}\text { Hansen 1994, } \\
\text { Hansen and Flake } 1995\end{array}$ & Idaho & Shrubsteppe, woodland & $\begin{array}{l}\text { Nested in narrowleaf cottonwood, water birch (Betula } \\
\text { occidentalis), and Utah juniper (Juniperus osteosperma); } \\
\text { mean height of nests was about } 4 \text { m and mean height of } \\
\text { nesting substrate was about } 6 \mathrm{~m} \text {; median diameter at breast } \\
\text { height (dbh) of nest trees was } 29 \mathrm{~cm} \text {; most nest trees were } \\
\text { within } 40 \text { m of an adjacent tree; nest sites had more } \\
\text { primary and secondary roads nearby than did random } \\
\text { points; mean distance from nests to buildings was } 8.9 \mathrm{~km} \text {, } \\
\text { to primary roads was } 3.4 \mathrm{~km} \text {, and to secondary roads was } \\
2.8 \mathrm{~km} \text {; mean length of road within } 3 \text { km of nests was } 20.6 \\
\mathrm{~km}\end{array}$ \\
\hline James 1992 & Saskatchewan & Urban & Nested in residential areas; nests were built in trees in \\
\hline
\end{tabular}




\begin{tabular}{|c|c|c|c|}
\hline & & & $\begin{array}{l}\text { private yards, in a railway signal gantry above a road, in a } \\
\text { city park, in coniferous trees (Black Hills spruce [Picea } \\
\text { glauca], blue spruce }[P . \text { pungens]), and in maple (Acer } \\
\text { spp.) trees }\end{array}$ \\
\hline Johnsgard 1980 & Nebraska & $\begin{array}{l}\text { Cropland, hayland, idle, } \\
\text { idle mixed-grass, idle } \\
\text { tallgrass, wet meadow }\end{array}$ & $\begin{array}{l}\text { Found in high plains and sandhills with only scattered } \\
\text { trees }\end{array}$ \\
\hline Leslie 1992 & Colorado & $\begin{array}{l}\text { Cropland, idle, mixed- } \\
\text { grass pasture, shortgrass } \\
\text { pasture, woodland }\end{array}$ & $\begin{array}{l}\text { Nested in grassland, abandoned fields, cultivated land, } \\
\text { riparian areas, windbreaks, and grazed grasslands; of } 157 \\
\text { nests, } 63 \text { were in lone trees, } 56 \text { were in small groves of } \\
<10 \text { trees, and } 38 \text { were in large groves of } \geq 10 \text { trees; of } 153 \\
\text { nests, } 76 \text { were in cottonwood, } 34 \text { were in willow, and } 43 \\
\text { were in introduced tree species; introduced species } \\
\text { included Chinese elm and Russian olive; average } \\
\text { measurements for nest trees were } 11.6 \text { m tree height, } 53.2 \\
\text { cm dbh, and } 12.1 \text { m crown width }\end{array}$ \\
\hline Maher 1974 & Saskatchewan & $\begin{array}{l}\text { Burned mixed-grass, idle } \\
\text { mixed-grass, mixed- } \\
\text { grass hayland, mixed- } \\
\text { grass pasture, woodland }\end{array}$ & $\begin{array}{l}\text { Nested in poplars growing in coulees and in quaking aspen } \\
\text { (Populus tremuloides) groves }\end{array}$ \\
\hline Martell et al. 1998 & Minnesota & $\begin{array}{l}\text { Cropland, idle tallgrass, } \\
\text { pasture }\end{array}$ & $\begin{array}{l}\text { Nested in woodlots, shelterbelts, and lone trees in or near } \\
\text { areas of intensive agriculture; nests were built in } \\
\text { cottonwood, ash, box elder, spruce, and red pine (Pinus } \\
\text { resinosa) }\end{array}$ \\
\hline Munro and Reid 1982 & Manitoba & $\begin{array}{l}\text { Cropland, idle mixed- } \\
\text { grass, pasture }\end{array}$ & $\begin{array}{l}\text { Four nests were surrounded by small-grain fields and four } \\
\text { were near native grass or pasture; all nests were near the } \\
\text { tops of quaking aspen at heights of } 4.3-11.2 \mathrm{~m} \text { from top of } \\
\text { nest to the ground }\end{array}$ \\
\hline
\end{tabular}




\begin{tabular}{|c|c|c|c|}
\hline Murphy 1991, 1993 & North Dakota & $\begin{array}{l}\text { Burned mixed-grass, } \\
\text { burned tame, idle mixed- } \\
\text { grass, idle tame, mixed- } \\
\text { grass pasture, tame } \\
\text { pasture, wetland }\end{array}$ & $\begin{array}{l}\text { Nested in trees or shrubs; mean nest-tree measurements } \\
\text { were } 21.41 \mathrm{~cm} \text { dbh, } 10.09 \mathrm{~m} \text { tree height, } 8.25 \mathrm{~m} \text { nest } \\
\text { height, and } 8.31 \mathrm{~m} \text { to edge of tree clump }\end{array}$ \\
\hline Olendorff 1973 & Colorado & $\begin{array}{l}\text { Cropland, idle } \\
\text { shortgrass, shortgrass } \\
\text { pasture, woodland }\end{array}$ & $\begin{array}{l}\text { Of } 150 \text { nests, all were in trees, } 90 \text { were located in creek } \\
\text { bottoms, grasslands, or cultivated land, and } 60 \text { were } \\
\text { located on human-created structures; abandoned } \\
\text { farmsteads were the most commonly used human-created } \\
\text { nesting site; nests on the Pawnee National Grassland were } \\
\text { more successful than nests on private lands; remote nests } \\
\text { or nests on posted land (i.e., with limited access or no } \\
\text { trespassing allowed) were more successful than easily } \\
\text { accessible nests or nests on unposted land; nests near a } \\
\text { road were more successful than nests away from roads; } \\
\text { however, nests near unimproved roads (trails used by } \\
\text { farmers) were more successful than nests near improved } \\
\text { (paved or gravel) roads, and nests near posted roads were } \\
\text { more successful than nests on unposted roads }\end{array}$ \\
\hline Prescott 1997 & Alberta & $\begin{array}{l}\text { Cropland, hayland, } \\
\text { mixed-grass pasture, } \\
\text { shrubland, tame pasture, } \\
\text { woodland }\end{array}$ & $\begin{array}{l}\text { Were most abundant in shelterbelts, followed by upland } \\
\text { shrubs, mixed-grass pasture, tame pasture, hayfield, fallow } \\
\text { cropland, upland trees, and cropland }\end{array}$ \\
\hline Restani 1991 & Montana & Pasture, woodland & $\begin{array}{l}\text { Nested in willows and Douglas fir (Pseudotsuga } \\
\text { menziesii); average nest measurements were } 5.1 \mathrm{~m} \text { height } \\
\text { of nest substrate, } 3.8 \mathrm{~m} \text { nest height, and } 7 \% \text { slope }\end{array}$ \\
\hline Salt and Salt 1976 & Alberta & $\begin{array}{l}\text { Cropland, idle, idle } \\
\text { grassland, parkland, }\end{array}$ & $\begin{array}{l}\text { Nested in bushes and trees such as birch (Betula), willow, } \\
\text { buffaloberry (Shepherdia argentea), and caragana }\end{array}$ \\
\hline
\end{tabular}




\begin{tabular}{|c|c|c|c|}
\hline & & pasture & (Caragana); nested infrequently on the ground \\
\hline Saunders 1914 & Montana & $\begin{array}{l}\text { Idle shortgrass, } \\
\text { woodland }\end{array}$ & $\begin{array}{l}\text { Nested in cottonwood trees and in pines at the base of } \\
\text { mountains }\end{array}$ \\
\hline Schmutz 1977 & Alberta & $\begin{array}{l}\text { Cropland, pasture, } \\
\text { wetland, woodland }\end{array}$ & $\begin{array}{l}\text { Nested on the ground, in planted trees, and on artificial } \\
\text { nesting structures; nest height averaged about } 4 \mathrm{~m}\end{array}$ \\
\hline $\begin{array}{l}\text { Schmutz 1984, 1987, } \\
1989\end{array}$ & Alberta & $\begin{array}{l}\text { Cropland, idle mixed- } \\
\text { grass, mixed-grass } \\
\text { pasture, tame hayland, } \\
\text { tame pasture, woodland }\end{array}$ & $\begin{array}{l}\text { Preferred cultivated land over grassland regardless of the } \\
\text { proportion of cultivated land in the nesting area; nest } \\
\text { density was higher on areas with } 11-30 \% \text { cultivation than } \\
\text { on areas with }<11 \% \text { cultivation, and nest densities } \\
\text { increased as cultivation increased to } 30 \% \text { and then showed } \\
\text { no further change; of } 37 \text { nesting pairs, } 57 \% \text { that nested } \\
\text { within } 1 \mathrm{~km} \text { of cultivated fields raised } \geq 2 \text { young, compared } \\
\text { to } 28 \% \text { of pairs that nested }>1 \mathrm{~km} \text { from cultivated fields; } \\
\text { of } 172 \text { nests, all were in trees; nested in windbreaks } \\
\text { surrounding farmyards }\end{array}$ \\
\hline Stewart 1975 & North Dakota & $\begin{array}{l}\text { Cropland, idle mixed- } \\
\text { grass, woodland }\end{array}$ & $\begin{array}{l}\text { Nested in areas of cropland or native prairie that included } \\
\text { brushy margins of native forested tracts, thickets of natural } \\
\text { trees, shelterbelts, or tree claims; nested in American elm, } \\
\text { bur oak (Quercus macrocarpa), peachleaf willow, } \\
\text { cottonwood, shrubs, ponderosa pine (Pinus ponderosa), } \\
\text { quaking aspen, box elder, green ash, hawthorn (Crataegus } \\
\text { spp.), plum (Prunus spp.), and balsam poplar (Populus } \\
\text { balsamifera); also nested on the ground; nest heights } \\
\text { ranged from } 0 \text { to } 18 \text { m with a mean of } 6 \mathrm{~m}\end{array}$ \\
\hline Thurow and White 1983 & Idaho & Desert shrubsteppe & Nested in Utah juniper \\
\hline
\end{tabular}

*In an effort to standardize terminology among studies, various descriptors were used to denote the management or type of habitat. "Idle" used as a modifier (e.g., idle tallgrass) denotes undisturbed or unmanaged (e.g., not burned, mowed, or grazed) areas. "Idle" by itself denotes unmanaged areas in which the plant species were not mentioned. Examples of "idle" habitats include weedy or fallow areas (e.g., oldfields), fencerows, grassed waterways, terraces, ditches, and road rights-of-way. "Tame" denotes introduced plant species (e.g., smooth brome [Bromus inermis]) that are not native to North American prairies. "Hayland" 
refers to any habitat that was mowed, regardless of whether the resulting cut vegetation was removed. "Burned" includes habitats that were burned intentionally or accidentally or those burned by natural forces (e.g., lightning). In situations where there are two or more descriptors (e.g., idle tame hayland), the first descriptor modifies the following descriptors. For example, idle tame hayland is habitat that is usually mowed annually but happened to be undisturbed during the year of the study. 


\section{LITERATURE CITED}

Andersen, D. E. 1995. Productivity, food habits, and behavior of Swainson's Hawks breeding in southeast Colorado. Journal of Raptor Research 29:158-165.

Bent, A. C. 1961. Life histories of North American birds of prey, Part 1. Dover Publications, Inc., New York, New York. 409 pages.

Cable, T. T., R. L. Schroeder, V. Brack, Jr., and P. S. Cook. 1992. Summer bird use of Kansas windbreaks. Prairie Naturalist 24:175-184.

Cameron, E. S. 1913. Notes on Swainson’s Hawk (Buteo swainsoni) in Montana. Auk 30:167176 and 381-394.

Clark, T. W., T. W. Campbell, III, D. G. Socha, and D. E. Cassey. 1982. Prairie dog colony attributes and associated vertebrate species. Great Basin Naturalist 42:572-582.

Dunkle, S. W. 1977. Swainson’s Hawk on the Laramie Plains, Wyoming. Auk 94:65-71.

Emmerich, J. M. 1978. Bird utilization of woodland habitat in the eastern quarter of South Dakota. M.S. thesis. South Dakota State University, Brookings, South Dakota. 130 pages.

England, A. S., M. J. Bechard, and C. S. Houston. 1997. Swainson’s Hawk (Buteo swainsoni). In A. Poole and F. Gill, editors. The birds of North America, No. 265. The Academy of Natural Sciences, Philadelphia, Pennsylvania; The American Ornithologists’ Union, Washington, D.C.

Faanes, C. 1983. Breeding birds of wooded draws in western North Dakota. Prairie Naturalist 15:173-187.

Faanes, C. A., and G. R. Lingle. 1995. Breeding birds of the Platte River Valley of Nebraska. Jamestown, ND: Northern Prairie Wildlife Research Center home page. http://www.npwrc.usgs.gov/resource/distr/birds/platte/platte.htm (Version 02SEP99).

Fyfe, R. W., and R. R. Olendorff. 1976. Minimizing the dangers of nesting studies to raptors and other sensitive species. Canadian Wildlife Service, Occasional Paper 23. 17 pages.

Gilmer, D. S., and R. E. Stewart. 1984. Swainson’s Hawk nesting ecology in North Dakota. Condor 86:12-18.

Green, G. A., and M. L. Morrison. 1983. Nest-site selection of sympatric Ferruginous and Swainson's hawks. Murrelet 64:20-22.

Groskorth, L. C. 1995. Nest-site selection by the Swainson's Hawk on the Regina Plain, Saskatchewan. Canadian Journal of Zoology 73:1887-1890. 
Haas, C. A. 1997. What characteristics of shelterbelts are important to breeding success and return rate of birds? American Midland Naturalist 137:225-238.

Hansen, R. W. 1994. Raptor use of the Idaho National Engineering Laboratory. M.S. thesis. South Dakota State University, Brookings, South Dakota. 141 pages.

Hansen, R. W., and L. D. Flake. 1995. Ecological relationships between nesting Swainson's and Red-tailed hawks in southeastern Idaho. Journal of Raptor Research 29:166-171.

Houston, C. S. 1990. Saskatchewan Swainson’s Hawks. American Birds 44:215-220.

Houston, C. S. 1995. The Swainson's Hawk productivity crash. Journal of Raptor Research 29:51.

Houston, C. S. 1998. Swainson’s Hawk productivity and five-young nest. Blue Jay 56:151155.

Houston, C. S., G. A. Fox, and R. D. Crawford. 1991. Unhatched eggs in Swainson's Hawk nests. Journal of Field Ornithology 62:479-485.

Jacobson, W. B. 1972. Relative abundance of the avian population along the South Platte River flood plain at the proposed Narrows Reservoir site. M.A. thesis. University of Northern Colorado, Greeley, Colorado. 82 pages.

James, P. C. 1992. Urban-nesting of Swainson’s Hawks in Saskatchewan. Condor 94:773-774.

Janssen, R. B. 1987. Birds in Minnesota. University of Minnesota Press, Minneapolis, Minnesota. 352 pages.

Johnsgard, P. A. 1980. A preliminary list of the birds of Nebraska and adjacent Plains states. University of Nebraska, Lincoln, Nebraska. 156 pages.

Johnson, C. G., L. A. Nickerson, and M. J. Bechard. 1987. Grasshopper consumption and summer flocks of nonbreeding Swainson’s Hawks. Condor 89:676-678.

Knopf, F. L. 1996. Mountain Plover (Charadrius montanus). A. Poole and F. Gill, editors. The birds of North America, No. 211. The Academy of Natural Sciences, Philadelphia, Pennsylvania; The American Ornithologists’ Union, Washington, D.C. 16 pages.

Krause, H. 1968. McCown’s Longspur. Pages 1564-1597 in O. L. Austin, Jr., editor. Life histories of North American cardinals, grosbeaks, buntings, towhees, finches, sparrows, and allies, part 3. Dover Publications, Inc., New York, New York.

Leslie, D. G. 1992. Population status, habitat and nest-site characteristics of a raptor community in eastern Colorado. M.S. thesis. Colorado State University, Fort Collins, Colorado. 45 pages. 
Maher, W. J. 1974. Matador Project: Birds II. Avifauna of the Matador area. Canadian Committee for the International Biological Programme, Matador Project, Technical Report 58. University of Saskatchewan, Saskatoon, Saskatchewan. 31 pages.

Martell, M., S. Willey, and J. Schladweiler. 1998. Nesting and migration of Swainson's Hawks in Minnesota. Loon 70:72-81.

McGrath, B. E. 1998. Saskatchewan flock of Swainson’s Hawks. Blue Jay 46:90.

Munro, H. L., and D. A. Reid. 1982. Swainson’s Hawks, Buteo swainsoni, nesting near Winnipeg. Canadian Field-Naturalist 96:206-208.

Murphy, R. K. 1991. Ecology and management of prairie raptors. Proceedings of the Nongame Wildlife Workshop. U.S. Fish and Wildlife Service, Region 6. 10 pages.

Murphy, R. K. 1993. History, nesting biology, and predation ecology of raptors in the Missouri Coteau of northwestern North Dakota. Ph.D. dissertation. Montana State University, Bozeman, Montana. 212 pages.

National Geographic Society. 1999. Field guide to the birds of North America, third edition. National Geographic Society, Washington, D.C. 480 pages.

Noble, D. G., and J. E. Elliot. 1990. Levels of contaminants in Canadian raptors, 1966 to 1988 : effects and temporal trends. Canadian Field-Naturalist 104:222-243.

Olendorff, R. R. 1973. The ecology of the nesting birds of prey of northeastern Colorado. U.S. International Biological Program, Grassland Biome Technical Report 211. Colorado State University, Fort Collins, Colorado. 233 pages.

Olendorff, R. R., and J. W. Stoddart, Jr. 1974. Potential for management of raptor populations in western grasslands. Pages 47-88 in F. N. Hamerstrom, Jr., B. E. Harrell, and R. R. Olendorff, editors. Management of Raptors: Raptor Research Report 2. Raptor Research Foundation, Inc., Vermillion, South Dakota.

Prescott, D. R. C. 1997. Avian communities and NAWMP habitat priorities in the northern prairie biome of Alberta. NAWMP-029. Land Stewardship Centre of Canada, St. Albert, Alberta. 41 pages.

Restani, M. 1991. Resource partitioning among three Buteo species in the Centennial Valley, Montana. Condor 93:1007-1010.

Salt, W. R., and J. R. Salt. 1976. The birds of Alberta. Hurtig Publishers, Edmonton, Alberta. 498 pages.

Saunders, A. A. 1914. The birds of Teton and northern Lewis and Clark counties, Montana. Condor 16:124-144. 
Schmutz, J. K. 1977. Relationships between three species of the genus Buteo (Aves) coexisting in the prairie-parkland ecotone of southeastern Alberta. M.S. thesis. University of Alberta, Edmonton, Alberta. 126 pages.

Schmutz, J. K. 1984. Ferruginous and Swainson's hawk abundance and distribution in relation to land use in southeastern Alberta. Journal of Wildlife Management 48:1180-1187.

Schmutz, J. K. 1987. The effect of agriculture on Ferruginous and Swainson's hawks. Journal of Range Management 40:438-440.

Schmutz, J. K. 1989. Hawk occupancy of disturbed grasslands in relation to models of habitat selection. Condor 91:362-371.

Schmutz, J. K. 1991. Age-related differences in reproductive success among Ferruginous and Swainson's hawks in Alberta. Journal of Raptor Research 25:160.

Schmutz, J. K., R. W. Fyfe, D. A. Moore, and A. R. Smith. 1984. Artificial nests for Ferruginous and Swainson's hawks. Journal of Wildlife Management 48:1009-1013.

Stewart, R. E. 1975. Breeding birds of North Dakota. Tri-College Center for Environmental Studies, Fargo, North Dakota. 295 pages.

Thurow, T. L., and C. M. White. 1983. Nest site relationship between Ferruginous Hawk and Swainson’s Hawk. Journal of Field Ornithology 54:401-406.

Torrance, D. J. 1986. Reproductive success of Swainson's Hawks in two habitats in southwestern Alberta. M.S. thesis. University of Calgary, Calgary, Alberta. 116 pages. 